\title{
PENGAMBILAN KEPUTUSAN PENEMPATAN JABATAN STRUKTURAL APARATUR SIPIL NEGARA (ASN)
}

\section{DECISION MAKING STRUCTURAL POSITION PLACEMENT STATE CIVIL APARATURE}

\author{
M. Yusuf S. Barusman ${ }^{*}$, Amelia Citra ${ }^{* *)}$, Moh. Oktavianur ${ }^{* * *}$, dan Appin Purisky Redaputri ${ }^{* * * *) 1}$ \\ *) Fakultas Ekonomi dan Bisnis, Universitas Bandar Lampung \\ Jl. Zainal Abidin Pagar Alam No.26, Labuhan Ratu, Kedaton, Bandar Lampung 35142, Indonesia \\ $\left.{ }^{* *}\right)$ Magister Managemen, Fakultas Ekonomi dan Bisnis, Universitas Bandar Lampung \\ J1. Zainal Abidin Pagar Alam No.26, Labuhan Ratu, Kedaton,Bandar Lampung 35142, Indonesia \\ ${ }^{* * *)}$ Fakultas Ilmu Sosial dan Politik, Universitas Bandar Lampung \\ Jl. Zainal Abidin Pagar Alam No.26, Labuhan Ratu, Kedaton, Bandar Lampung 35142, Indonesia
}

\begin{abstract}
Employees are a very important resource for determining the success of a work unit. Efforts to improve the quality of the performance of an ASN is a promotion. The promotion is an award given for work performance and service of ASN, as well as encouragement to further improve work performance and service. One of the main causes is because there is a mismatch between the competencies of employees with the positions they occupy. The discrepancy is caused by the composition of expertise or skills of employees who have not been proportionate. Therefore, it is necessary to have an assessment in determining promotions by taking into account several elements, including formal and informal elements. In both elements there are special criteria as a basis for making an assessment. The method used in this research is Soft System Methodology (SSM) using Analytical Hierarchy Process tools. From the results of the study obtained two criteria, namely Formal and Informal. Formal criteria consist of formal education sub rank, rank / goal. space, position training, job experience, years of service, and age, while innovation, creativity, and ideas for developing institutional functions, discipline, ability to collaborate and cooperate with teams, leadership, loyalty, responsibility, ability to communicate well, and political intervention is a subcriterion of informal criteria.
\end{abstract}

Keywords: decision making, position placement system, state civil aparature, soft system methodology, analytical hierarchy process

\begin{abstract}
Abstrak: Pegawai merupakan sumber daya yang sangat penting untuk menentukan keberhasilan suatu satuan kerja. Upaya meningkatkan kualitas kinerja seorang ASN yaitu dengan adanya kenaikan jabatan. Kenaikan jabatan adalah penghargaan yang diberikan atas prestasi kerja dan pengabdian ASN, serta sebagai dorongan untuk lebih meningkatkan prestasi kerja dan pengabdiannya. Salah satu penyebab utamanya karena terjadi ketidaksesuaian antara kompetensi pegawai dengan jabatan yang didudukinya. Ketidaksesuaian itu disebabkan oleh komposisi keahlian atau keterampilan pegawai yang belum proporsional. Oleh karena itu, perlu adanya penilaian dalam menentukan kenaikan jabatan dengan memperhatikan beberapa unsur, diantaranya unsur formal dan informal. Pada kedua unsur tersebut terdapat kriteria-kriteria khusus sebagai dasar dalam melakukan penilaian. Metode yang digunakan dalam penelitian ini yaitu Soft System Methodology (SSM) dengan menggunakan tools Analytical Hierarchy Process. Dari hasil penelitian diperoleh dua kriteria, yaitu formal dan informal. Kriteria formal terdiri atas subkriteria pendidikan formal, pangkat/Gol. ruang, diklat jabatan, pengalaman jabatan, masa kerja, dan usia, sedangkan inovasi, kreativitas, serta ide bagi pengembangan fungsi lembaga, disiplin, kemampuan berkolaborasi dan kerja sama dengan tim, leadership, loyalitas, tanggung jawab, kemampuan berkomunikasi dengan baik, dan intervensi politik merupakan subkriteria dari kriteria informal.
\end{abstract}

Kata kunci: pengambilan keputusan, sistem penempatan jabatan, aparatur sipil negara, soft system methodology, analytical hierarchy process

\footnotetext{
${ }^{1}$ Alamat korespondensi:
}

Email: appin@ubl.ac.id 


\section{PENDAHULUAN}

Profesionalisme Aparatur Sipil Negara (ASN) selaku penyelenggara masih belum sesuai dengan yang diharapkan. Salah satu penyebab utamanya karena terjadi ketidaksesuaian antara kompetensi pegawai dengan jabatan yang didudukinya. Ketidaksesuaian itu disebabkan oleh komposisi keahlian atau keterampilan pegawai yang belum proporsional. Demikian pula, pendistribusian pegawai masih belum mengacu pada kebutuhan nyata organisasi, dalam arti belum didasarkan pada beban kinerja organisasi. Menumpuknya pegawai disatu unit tanpa pekerjaan yang jelas dan kurangnya pegawai diunit lain merupakan kenyataan dari permasalahan tersebut. Berbagai upaya dilakukan untuk dapat meningkatkan kualitas dari aparatur negara.

Pegawai merupakan sumber daya yang sangat penting untuk menentukan keberhasilan suatu satuan kerja baik dalam pengabdian maupun pelayanan. Upaya meningkatkan kualitas kinerja seorang ASN yaitu adanya kenaikan jabatan. Jabatan merupakan kedudukan yang menunjukan tingkat seorang ASN. Kenaikan jabatan adalah penghargaan yang diberikan atas prestasi kerja dan pengabdian ASN, serta sebagai dorongan untuk lebih meningkatkan prestasi kerja dan pengabdiannya. Oleh karena, itu perlu adanya penilaian dalam menentukan kenaikan jabatan.

Saat ini masih ditemukan keputusan kepala daerah dalam menempatkan seorang pegawai, seringkali bukanlah didasarkan pada ketentuan yang berlaku, melainkan lebih didasarkan pada kepentingan politik dan faktor like and dislike. Bahri S et al. (2016) menjelaskan bahwa fenomena umum yang terjadi saat ini adalah pengangkatan pegawai negeri sipil dalam posisi struktural di Indonesia kontroversial berbagai kelompok praktisi dan secara teoritis bahkan suara dari publik itu sendiri. Di mana masalah bahwa perilaku pengambil keputusan mengabaikan standar dan juga prinsip-prinsip kompetensi, sehingga keputusan yang dihasilkan itu tidak mencerminkan tujuan organisasi tetapi menekankan kepentingan pribadi. Stephen dan Mary (2010), keputusan adalah suatu pilihan yang dibuat dari alternatif. Proses pengambilan keputusan merupakan serangkaian tahap yang terdiri dari delapan langkah yang meliputi mengidentifikasi masalah, memilih suatu alternatif, dan mengevaluasi suatu keputusan. Pengambilan keputusan erat kaitannya dengan upaya untuk memecahkan masalah atau potensi masalah yang dihadapi seseorang atau organisasi (muhdi et al. 2017). Decision Support System atau Sistem Pendukung Keputusan yang selanjutnya kita singkat dalam menjadi SPK, secara umum didefinisikan sebagai sebuah sistem yang mampu memberikan kemampuan pemecahan masalah maupun kemampuan pemgkomunikasian untuk masalah semi terstruktur. Secara khusus, SPK didefinisikan sebagai sebuah sistem yang mendukung kerja seorang manajer maupun sekelompok manajer dalam memecahkan masalah semiterstruktur dengan cara memberikan informasi ataupun usulan menuju pada keputusan tertentu (Hermawan, 2005). Pimpinan daerah atau para pengambil kebijakan biasanya sengaja memilih orang-orang yang disukai atau memiliki hubungan kedekatan/kekerabatan untuk diangkat atau ditunjuk menempati suatu jabatan strategis. Realitas demikian menimbulkan implikasi luas pada pendistribusian sumber daya manusia yang cenderung tidak didasarkan pada pendekatan profesionalisme, melainkan lebih dominan kepada pendapat politik semata. Selain itu menurut Alonso et al. 2019, DSS adalah alat berbasis komputer interaktif untuk meningkatkan proses pengambilan keputusan dan membimbing pengambil keputusan dalam semi terstruktur atau, kadang-kadang, pemecahan masalah tidak terstruktur. DSS mengintegrasikan teknik dari: statistik, sistem informasi klinis, pemodelan komputasi, simulasi dan pembelajaran mesin.

Teknologi yang semakin berkembang pada saat ini sangat mendukung kebutuhan suatu instansi. Baik untuk mewujudkan efektivitas dan efisiensi kerja maupun dalam meningkatkan pelayanan kepada masyarakat. Terutama sistem yang dapat membantu dan memberikan keputusan,agar keputusan yang dikeluarkan instansi lebih bersifat relevan dan dapat diterima semua pihak. informasi merupakan hal yang sangat penting bagi manajemen didalam mengambil keputusan. Pengertian Sistem Informasi Menurut Kenneth (2007) adalah satuan komponen yang saling berhubungan yang mengumpulkan, memproses, menyimpan dan mendistribusikan informasi untuk mendukung pengambilan keputusan dan kendali dalam suatu organisasi. Menurut Jogiyanto (2001) Sistem (systems) adalah kumpulan dari elemen-elemen yang berinteraksi untuk mencapai suatu tujuan sertentu. Menurut Barusman (2017): Sistem telah berkembang menjadi semakin kompleks, dinamis, saling terhubung, dan terotomatisasi. Dengan adanya systems thinking, akan tersedia suatu filosofi holistic dengan kemampuan membuka struktur sistem yang critical seperti batasan (boundaries), input, output, spatial orientation, 
struktur proses, dan interaksi yang kompleks antara sistem dengan lingkungannya.

Permasalah penentuan penempatan jabatan struktural ini melibatkan berbagai faktor dan termasuk pengambilan keputusan yang kompleks. Untuk itu diperlukan berpikir tersistem dan analisis dengan menggunakan Soft Systems Methodology khususnya pengambilan keputusan dengan menggunakan Analytical Hierarchy Process. Soft Systems Methodology (SSM) adalah metodologi yang dikembangkan dalam menanggapi keterbatasan pendekatan rekayasa sistem. Ini menggunakan proses yang fleksibel, tetapi terorganisir untuk menghasilkan tindakan guna memperbaiki situasi yang problematis (Proches et al. 2015). Salah satu alat analisis yang bisa digunakan adalah Analytical Hierarchy Process (AHP). Menurut Kustituanto et al. (2001) AHP dirancang untuk mengetahui persepsi orang yang berhubungan erat dengan tujuan/permasalahan tertentu melalui prosedur yang dirancang untuk sampai pada suatu skala preferensi di antara berbagai alternatif.

Aparatur Sipil Negara merupakan salah satu bagian dari pegawai Dinas Perkebunan dan Peternakan Provinsi Lampung. Peran sistem pendukung keputusan sangat dibutuhkan guna meningkatkan efisensi pengambilan keputusan. Peran sistem pendukung keputusan akan membantu pihak kepegawaian dalam capai tujuan dari peneliaian kinerja pegawai, seperti kenaikan jabatan, tanpa mengesampingkan kriteria-kriteria yang sudah ditentukan oleh pihak instansi terkait. Selama ini, penilaian kinerja pegawai di Dinas Perkebunan dan Peternakan Provinsi Lampung, dilakukan oleh bagian kepegawaian yang berkoordinasi dengan kepala instansi. Dibutuhkan sistem pendukung keputusan guna membantu dalam menentukan penilaian atas kinerja pegawai untuk tujuan kenaikan jabatan struktural dengan menggunakan suatu metode.

\section{METODE PENELITIAN}

Objek penelitian ini adalah pengambilan keputusan sistem penempatan jabatan struktural ASN pada Dinas Perkebunan dan Peternakan Provinsi Lampung. Penelitian ini dilakukan pada Tahun 2019. Data yang digunakan menggunakan data primer yang diambil dari hasil Deep Structure interview dari para narasumber. Narasumber yang akan digali informasinya mengenai sistem penempatan jabatan struktural ASN adalah
Senior-senior yang sedang atau pernah menduduki jabatan struktural di pemerintahan, antara lain : Ir. Sutono selaku Sekretaris Daerah Provinsi Lampung (2016-2019). Ir. Kusnardi,M.Agr., Ec selaku Kepala Dinas Perkebunan dan Peternakan Provinsi Lampung Tahun 2018 sampai dengan sekarang, dan Ir. Edi Yanto, M.Si, selaku kepala dinas ketahanan pangan rovinsi Lampung dan Kepada Badan Perencanaan Daerah Provinsi Lampung periode ( 2010-2011).

Pra Riset dilakukan dengan wawancara mendalam (Deep Structure Interview) adalah proses memperoleh keterangan untuk tujuan penelitian dengan cara tanya jawab sambil bertatap muka antara pewawancara dengan orang yang diwawancarai dengan atau tanpa menggunakan pedoman (guide) wawancara dimana pewawancara dan informan terlibat dalam kehidupan sosial yang relatif lama (Sutopo, 2006). Tujuan wawancara mendalam dalam penelitian ini adalah untuk mengetahui kriteria-kriteria apa saja yang diperlukan dalam melakukan penilaian terhadap ASN dalam rangka penempatan jabatan struktural. Dalam penelitian ini dilakukan Deep Structure Interview dengan beberapa Narasumber yang menguasai dan berpengalaman dalam melakukan penilaian terhadap Aparatur Sipil Negara di Provinsi Lampung.

Tools atau alat yang digunakan dalam penelitian ini adalah Analytical Hierarchy Process (AHP). Tujuan dari AHP ini adalah untuk menyederhanakan faktorfaktor yang didapat pada saat melakukan wawancara khususnya Deep Structure Interview (DSI) ke dalam suatu hirarki sehingga tampak lebih terstruktur dan sistematis. Wawancara adalah salah satu teknik pengumpulan data untuk peneliti kualitatif. Berbeda dari metode lain, wawancara memiliki fitur unik yang membuatnya unggul (Adhabi et al. 2017). Metode yang relevan serta memiliki penghitungan nilai konsistensi dalam menentukan tingkat prioritas kriteria adalah metode AHP (Munthafa et al. 2017). AHP sering digunakan sebagai metode pemecahan masalah dibanding dengan metode yang lain karena alasan-alasan sebagai berikut: 1 . Struktur yang berhierarki, sebagai konsekuesi dari kriteria yang dipilih, sampai pada subkriteria yang paling dalam; 2. Memperhitungkan validitas sampai dengan batas toleransi inkonsistensi berbagai kriteria dan alternatif yang dipilih oleh pengambil keputusan; 3. Memperhitungkan daya tahan output analisis sensitivitas pengambilan keputusan (Pebakirang et al. 2017). 
Pengumpulan data dalam penelitian ini agar didapatkan data yang lebih mendalam, maka dilakukan Deep structure Interview (DSI) dengan para praktisi yang berpengalaman dan kompeten dalam melakukan penilaian terhadap ASN. Selain itu juga dilakukan penyebaran kusioner, sehingga didapatkan data yang akurat dan analisis yang mendalam. Metode penelitian menggunakan Soft System Methodology (SSM), yaitu dengan mengedepankan prinsip Cybernetic (memiliki tujuan), Holistic (keseluruhan), dan Efective ( dapat dipakai dalam pengambilan keputusan Penelitian ini menggunakan pendekatan Soft System Methodology (SSM) dikarenakan penelitian ini membutuhkan pendekatan sistem yang kompleks dengan permasalahan yang tidak terstruktur dan terus berkembang yang memiliki tujuan tertentu, yaitu membuat model yang bisa diaplikasikan, terutama dalam hal penempatan jabatan ASN struktural pada Dinas Perkebunan dan Peternakan Provinsi Lampung. Dalam Barusman (2018) disebutkan bahwa SSM adalah pendekatan holistik dalam melihat aspek nyata dan konseptual dalam masyarakat. SSM melihat setiap hal yang terjadi sebagai sistem aktivitas manusia karena rangkaian aktivitas manusia dapat disebut sebagai sistem, yang mana masing-masing aktivitas berhubungan satu sama lain dan membentuk ikatan. Soft System Methodology (SSM) pertama kali diperkenalkan di Inggris oleh Tim akademisi dari Universitas Lancaster yang dipimpin oleh Prof. Gwilym Jenkins pada tahun 1966. SSM awalnya digunakan untuk membantu menyelesaikan masalah yang begitu kompleks dan melibatkan banyak stakeholder di dalam bidang manajemen. Pendekatan ini digunakan ketika pendekatan teknikal tidak mampu menjelaskan berbagai fenomena yang dihadapi secara utuh dan akurat. SSM dikembangkan oleh para teknisi manajemen di Universitas Lancaster untuk membantu menyelesaikan masalah terkait dengan efisiensi dan efektivitas yang melibatkan teknologi modern dengan kompleksitas tinggi dalam organisasi manusia. Ide dasar dari pemikiran soft system adalah konsep sistem yang digunakan sebagai cara untuk menyelidiki kedalam dunia yang dipersepsikan. Ide-ide sistem berdasarkan konsep keseluruhan dimana suatu organisasi dapat dilihat sebagai suatu keseluruhan yang utuh dimana suatu keseluruhan dapat menggambarkan sifat-sifat emergent. Sifat-sifat dari bagian yang tidak mempunyai arti jika tidak dalam konteks keseluruhan.

Selalu ada beberapa perspektif berbeda dari dunia karena dunia dibentuk oleh pengalaman, latar belakang, pendidikan, kultur, dan perhatian orang-orang yang mempersepsikannya. Oleh karena itu, tidak ada persepsi yang benar di dunia nyata. Dunia ini sangat kompleks, problematikal, dan misterius. Tetapi, diasumsikan bahwa proses penyelidikannya dapat diorganisasikan sebagai suatu sistem. Akibatnya penggunaan istilah sistem tidak lagi diaplikasikan ke dalam dunia, tetapi pada proses kita menghadapi dunia.

Sehingga bisa disimpulkan bahwa Soft System Methodology (SSM) adalah sebuah pendekatan holistik didalam melihat aspek-aspek riil dan konseptual di masyarakat. SSM melihat setiap yang terjadi sebagai Human Activity System, karena serangkaian aktivitas manusia dapat disebut sebagai sebuah sistem, yaitu setiap aktivitas-aktivitas tersebut saling berhubungan dan membentuk suatu ikatan. Pendekatan Soft System dianggap sebagai metodologi yang sangat produktif untuk mempelajari setiap aktivitas manusia yang terorganisir didalam mencapai tujuan-tujuan tertentu.

Tools (alat) yang digunakan dalam penelitian ini yaitu analisis situasional dengan melalui interview, study literature, dan tools AHP (Analytical Hierarchy Process). Analytical Hierarchy Process (AHP) dikembangkan oleh Thomas L. Saaty pada tahun 1970an. AHP merupakan sistem pembuat keputusan dengan menggunakan model matematis. AHP membantu dalam menentukan prioritas dari beberapa kriteria dengan melakukan analisis perbandingan berpasangan dari masing-masing kriteria. AHP juga merupakan suatu model yang luwes yang memberikan kesempatan bagi perorangan atau kelompok untuk membangun gagasan-gagasan dan mendefinisikan persoalan dengan cara membuat asumsi mereka masing-masing dan memperoleh pemecahan yang diinginkan darinya. Dalam menyelesaikan persoalan dengan AHP (Saaty, 1993) ada beberapa prinsip yang harus dipahami diantaranya adalah sebagai berikut:

\section{Decompocition}

Setelah permasalahan didefinisikan, maka perlu dilakukan decompocition yaitu memecah permasalahan yang utuh menjadi unsur-unsurnya. Jika ingin mendapatkan hasil yang akurat, pemecahan juga dilakukan terhadap unsur-unsurnya sampai tidak mungkin dilakukan pemecahan lebih lanjut sehingga didapatkan beberapa tingkatan dari persoalan tadi. Karena alasan ini, maka proses analisis ini dinamakan hierarki. Ada dua jenis hierarki, yaitu hierarki lengkap dan tidak lengkap. Dalam hierarki lengkap, semua elemen pada suatu tingkat memiliki semua elemen 
yang ada pada tingkat berikutnya. Namun, jika tidak maka dinamakan hierarki tidak lengkap.

\section{Comparative Judgement}

Tahap ini adalah membuat penilaian tentang kepentingan relatif dua elemen pada suatu tingkat tertentu dalam kaitannya dengan tingkat di atasnya. Penilaian ini merupakan inti dari AHP, karena penilaian akan berpengaruh terhadap prioritas elemen-elemen. Hasil dari penilaian ini akan tampak lebih baik bila disajikan dalam bentuk matriks yang dinamakan matriks pairwase comparison. Pertanyaan yang biasa diajukan dalam penyusunan skala kepentingan adalah elemen mana yang lebih (penting/disukai/mungkin/..); berapa kali lebih (penting/disukai/mungkin/..).

Agar diperoleh skala yang bermanfaat ketika membandingkan dua elemen, seseorang yang akan memberikan jawaban perlu pengertian menyeluruh tentang elemen-elemen yang dibandingkan dan relevansinya terhadap kriteria atau tujuan yang ingin dicapai. Dalam penilaian kepentingan relatif dua elemen berlaku aksioma reciprocal artinya jika elemen i dinilai 3 kali lebih penting dibanding j maka elemen $\mathrm{j}$ harus sama dengan $1 / 3$ kali pentingnya dibanding elemen i. Disamping itu, perbandingan dua angka yang sama akan menghasilkan angka 1 , artinya sama penting. Dua elemen yang berlainan dapat saja dinilai sama penting. Jika terdapat $\mathrm{n}$ elemen, maka akan diperoleh matriks pairwise comparison berukuran $\mathrm{n} \times \mathrm{n}$.

\section{Synthesis of Priority}

Setiap matriks pairwise comparison kemudian dicari eigen vector untuk mendapatkan local priority, karena matriks pairwise comparison terdapat pada setiap tingkat, maka untuk mendapatkan global priority harus dilakukan sintesa diantara local priority. Prosedur melakukan sintesa berbeda menurut bentuk hierarki. Pengurutan elemen-elemen menurut kepentingan relatif melalui prosedur sintesa dinamakan priority setting.

\section{Logical Consistency}

Logical consistency menyatakan ukuran tentang konsisten tidaknya suatu penilaian atau pembobotan perbandingan berpasangan. Pengujian ini diperlukan, karena pada keadaan yang sebenarnya akan terjadi beberapa penyimpangan dari hubungan tersebut sehingga matriks tersebut tidak konsisten sempurna. Hal ini dapat terjadi karena ketidak konsistenan dalam preferensi seseorang.

Untuk menciptakan good governance dalam meningkatkan kinerja aparatur dalam memberikan pelayanan publik, sangat penting untuk memperhatikan manajemen sumber daya manusia dalam hal ini sistem penempatan jabatan sesuai dengan tugas pokok dan fungsinya. Proses penempatan jabatan yang memperhatikan kesesuaian pengetahuan, kesesuaian ketrampilan, dan kesesuaian sikap akan mempengaruhi kinerja organisasi dalam memberikan pelayanan yang maksimal bagi masyarakat umumnya. Adapun kerangka pemikiran dapat gambarkan pada Gambar 1 .

\section{HASIL}

Berdasarkan Suhud dan Dwiyanto dalam Mahmudah et al. (2018), dalam merancang suatu sistem berbasis metode AHP untuk pengambilan keputusan maka langkah awal yang harus dilakukan adalah mendefinisikan permasalahan dan penentuan tujuan dengan menyusunnya kedalam hierarki. Selanjutnya, menentukan kriteria yang akan diberikan bobotnya (Suhud dan Dwiyatno, 2014). Berdasarkan kriteria yang diperoleh dari hasil wawancara dengan narasumber, maka alternatif kriteria dengan prioritas terbesar berdasarkan bobot yang ada yaitu dalam menentukan pejabat struktural ASN yang tepat pada Disbunnak Provinsi Lampung terdiri dari kriteria formal dan informal. Untuk kriteria formal terdiri dari sub kriteria pendidikan formal, pangkat/gol ruang, diklat jabatan, pengalaman jabatan, masa kerja dan usia. Sedangkan kriteria informal terdiri dari subkriteria disiplin, inovasi, kreatifitas, ide pengembang fungsi lembaga, kemampuan berkolaborasi dan kerjasama dalam tim, loyalitas, tanggung jawab, leadership, kemampuan berkomunikasi dengan baik dan intervensi politik. Selanjutnya setelah mendapatkan kriteria formal dan informal dari hasil interview, disusun hierarki AHP yang menunjukkan keterkaitan antara tujuan, kriteria, subkriteria dan alternatif-alternatifnya. Mulai dari tujuan yaitu membangun sistem penempatan jabatan struktural ASN pada dinas perkebunan dan peternakan, kemudian dibagi menjadi kriteria formal dan informal yang terdiri dari masing-masing 6 dan 8 subkriteria dan 3 alternatif yang akan dipilih. Adapun hirarki AHP dapat dilihat pada Gambar 2. 


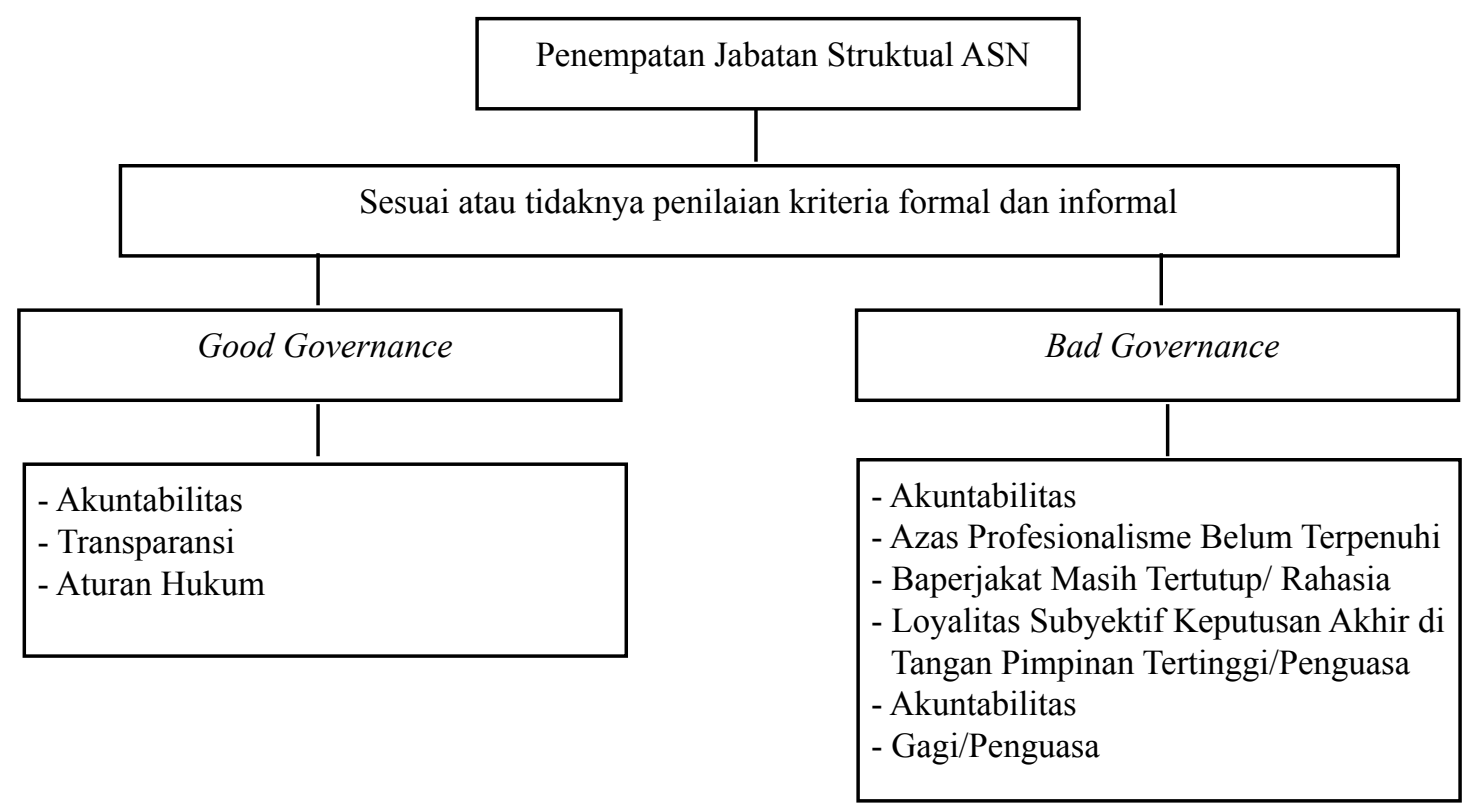

Gambar 1. Kerangka pemikiran penelitian

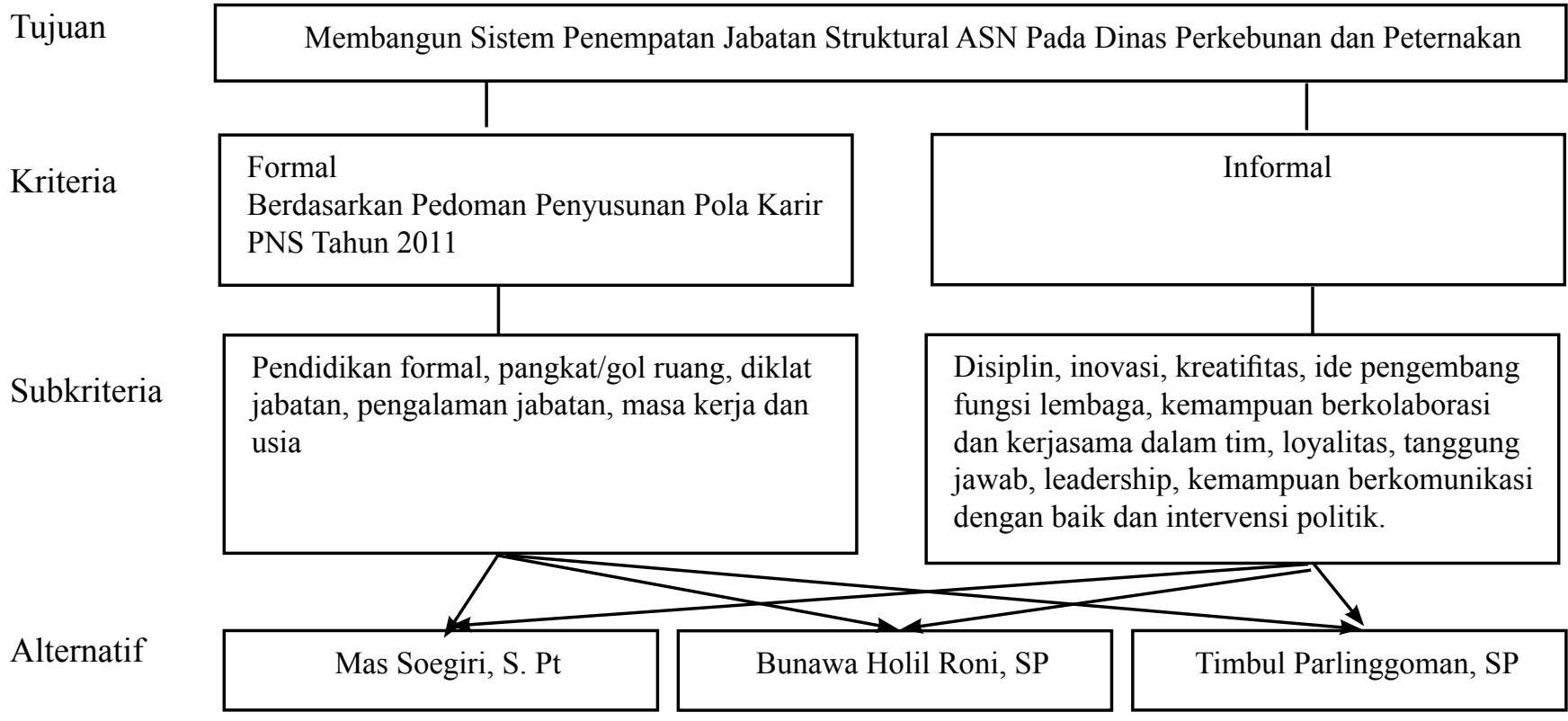

Gambar 2. Hierarki AHP

Dalam mengukur tingkat kepentingan antar sub kriteria, dilakukan pembobotan intensitas kepentingan dengan membandingan tingkat kepentingan antar variable. Pembobotan tersebut sesuai dengan teori AHP yang dapat dilihat pada Tabel 1. Setelah melalui tahap pembobotan menggunak metode AHP, selanjutnya dilakukan pengambilan sample yang terdiri dari pejabat struktural Eselon IV pada Disbunnak Provinsi Lampung sejumlah 3 orang. Ketiga pejabat struktutal tersebut dinilai melalui kuesioner oleh atasan langsung. Yaitu dalam hal ini ejabat Eselon III yang mengepalai masing-masing Eselon IV. Dari hasil penilaiann tersebut, maka didapatkan hasil yang dijabarkan pada Tabel 2. 
Tabel 1. Intensitas kepentingan antar subkriteria formal

\begin{tabular}{cl}
\hline Intensitas Pentingnya & \multicolumn{1}{c}{ Definisi } \\
\hline 1 & Kedua Elemen/ Alternatif sama pentingnya (equal) \\
3 & Elemen A sedikit lebih esensial dari elemen B (moderate) \\
5 & Elemen A lebih esensial dari elemen B (strong) \\
7 & Elemen A jelas lebih esensial dari elemen B (very strong) \\
9 & Elemen A mutlak lebih esensial dari elemen B (very strong) \\
$2,4,6,8$ & Nilai-nilai antara di antara dua perimbangan yang berdekatan \\
\hline
\end{tabular}

Tabel 2. Model pengambilan keputusan penempatan jabatan struktural ASN pada Dinas Perkebunan dan Peternakan Provinsi Lampung

\begin{tabular}{|c|c|c|c|c|c|c|c|}
\hline Alternatif & Bobot & $\begin{array}{l}\text { Mas Soegiri, } \\
\text { S. Pt. }\end{array}$ & $\begin{array}{c}\text { Jumlah } \\
\text { Nilai }\end{array}$ & $\begin{array}{l}\text { Bunawar Holil } \\
\text { Roni, Sp. }\end{array}$ & $\begin{array}{c}\text { Jumlah } \\
\text { Nilai }\end{array}$ & $\begin{array}{c}\text { Timbul } \\
\text { Parlinggoman, } \mathrm{Sp}\end{array}$ & $\begin{array}{c}\text { Jumlah } \\
\text { Nilai }\end{array}$ \\
\hline \multicolumn{8}{|l|}{ Kriteria Formal } \\
\hline Pendidikan Formal & 0,2 & 70 & 14 & 70 & 14 & 70 & 14 \\
\hline Pangkat / Gol. Ruang & 0,2 & 70 & 14 & 70 & 14 & 70 & 14 \\
\hline Diklat Jabatan & 0,2 & 60 & 12 & 80 & 16 & 60 & 12 \\
\hline Pengalaman Jabatan & 0,19 & 60 & 11,4 & 70 & 13,3 & 70 & 13,3 \\
\hline Masa Kerja & 0,19 & 70 & 13,3 & 70 & 13,3 & 70 & 13,3 \\
\hline Usia & 0,03 & 70 & 2,1 & 80 & 2,4 & 80 & 2,4 \\
\hline \multicolumn{8}{|l|}{ Kriteria Informal } \\
\hline $\begin{array}{l}\text { Inovasi, Kreatifitas, Ide } \\
\text { bagi pengembangan fungsi } \\
\text { lembaga }\end{array}$ & 0,22 & 80 & 17,76 & 70 & 15,54 & 80 & 17,76 \\
\hline Disiplin & 0,222 & 70 & 15,4 & 80 & 17,6 & 70 & 15,4 \\
\hline $\begin{array}{l}\text { Kemampuan berkolaborasi } \\
\text { dan kerjasama dalam tim }\end{array}$ & 0,22 & 80 & 7,2 & 70 & 6,3 & 70 & 6,3 \\
\hline Leadership & 0,09 & 70 & 6,3 & 80 & 7,2 & 70 & 6,3 \\
\hline Loyalitas & 0,09 & 80 & 7,2 & 80 & 7,2 & 70 & 6,3 \\
\hline Tanggung Jawab & 0,09 & 80 & 4 & 80 & 4 & 70 & 3,5 \\
\hline $\begin{array}{l}\text { Kemampuan berkomunikasi } \\
\text { dengan baik }\end{array}$ & 0,05 & 70 & 2,1 & 80 & 2,4 & 70 & 2,1 \\
\hline Intervensi Politik & 0,03 & 70 & 2,1 & 70 & 2,1 & 80 & 2,4 \\
\hline Jumlah & & & 128,86 & & 135,34 & & 129,06 \\
\hline
\end{tabular}

Langkah selanjutnya adalah melakukan perhitungan metode perbandingan eksponensial. Metode Perbandingan Eksponensial salah satu metode dari Sistem Pendukung Keputusan (SPK) yang digunakan untuk menentukan urutan prioritas alternatif keputusan dengan multi kriteria (Kriteria Majemuk) (Marimin, 2011). Atau dengan kata lain Metode Perbandingan Eksponensial adalah salah satu metode pengambilan keputusan yang mengkuantifikasikan pendapat seseorang atau lebih dalam skala tertentu. Jadi intinya metode ini digunakan untuk skoring terhadap pilihan yang ada. Adapun perhitungan perbandingan eksponensial untuk masing-masing alternatif yaitu sebagai berikut:
Alternatif 1 - Mas Soegiri, S. Pt

$\left(0,2^{\wedge} 70\right)+\left(0,2^{\wedge} 70\right)+\left(0,2^{\wedge} 60\right)+\left(0,19^{\wedge} 60\right)+\left(0,19^{\wedge} 70\right)+$

$\left(0,03^{\wedge} 70\right)+\left(0,22^{\wedge} 80\right)+\left(0,22^{\wedge} 70\right)+\left(0,22^{\wedge} 80\right)+\left(0,09^{\wedge} 70\right)$

$+\left(0,09^{\wedge} 80\right)+\left(0,09^{\wedge} 80\right)+\left(0,05^{\wedge} 70\right)+\left(0,03^{\wedge} 70\right)=128,86$

Alternatif 2 - Bunawar Holil Roni, SP

$\left(0,2^{\wedge} 70\right)+\left(0,2^{\wedge} 70\right)+\left(0,2^{\wedge} 80\right)+\left(0,19^{\wedge} 70\right)+\left(0,19^{\wedge} 70\right)+$

$\left(0,03^{\wedge} 80\right)+\left(0,22^{\wedge} 70\right)+\left(0,22^{\wedge} 80\right)+\left(0,22^{\wedge} 70\right)+\left(0,09^{\wedge} 80\right)$

$+\left(0,09^{\wedge} 80\right)+\left(0,09^{\wedge} 80\right)+\left(0,05^{\wedge} 80\right)+\left(0,03^{\wedge} 70\right)=135,34$

Alternatif 3 - Timbul Parlinggoman, SP

$\left(0,2^{\wedge} 70\right)+\left(0,2^{\wedge} 70\right)+\left(0,2^{\wedge} 60\right)+\left(0,19^{\wedge} 70\right)+\left(0,19^{\wedge} 70\right)+$

$\left(0,03^{\wedge} 80\right)+\left(0,22^{\wedge} 80\right)+\left(0,22^{\wedge} 70\right)+\left(0,22^{\wedge} 70\right)+\left(0,09^{\wedge} 70\right)$

$+\left(0,09^{\wedge} 70\right)+\left(0,09^{\wedge} 70\right)+\left(0,05^{\wedge} 70\right)+\left(0,03^{\wedge} 80\right)=129,06$ 
Berdasarkan hasil perhitungan perbandingan eksponensial diatas, dapat diketahui bahwa terdapat 3 (tiga) alternatif Eselon IV yang dapat dipromosikan menduduki jabatan struktural Eselon III pada Dinas Perkebunan dan Peternakan Provinsi Lampung mulai dari proritas pertama sampai ketiga, yaitu, untuk prioritas pertama adalah Bunawar Holil Roni, SP dengan nilai 135,34; Timbul Parlinggoman, SP untuk prioritas kedua dengan nilai 129,06; serta Mas Soegiri, S. Pt dengan nilai 128,86 sebagai prioritas ketiga.

\section{Implikasi Manajerial}

Untuk itu implikasi pada manajerialnya adalah bahwa hasil penelitian ini bisa menjadi salah satu dasar pengambilan keputusan penempatan pejabat eselon III pada Dinas Perkebunan dan Peternakan Provinsi Lampung. Untuk selajutnya, proses pengambilan keputusan penempatan pejabat eselon dari dinas lainnya dalam pemerintahan juga bisa menggunakan metode dan kriteria seperti yang ada pada penelitian ini. Seperti penempatan jabatan di pemerintahan provinsi, pemerintahan daerah dan dinas lainnya. Baik itu rotasi maupun promosi. Selain itu, kriteria yang berkaitan juga bisa disesuaikan dengan kondisi di dinas yang akan dijadikan objek penelitian.

\section{KESIMPULAN DAN SARAN}

\section{Kesimpulan}

Berdasarkan penelitian, analisis, serta pembahasan yang telah dilakukan pada bab sebelumnya, maka dapat diambil kesimpulan yaitu setelah dilakukan interview dengan narasumber, maka kriteria penilaian penempatan jabatan ASN dikategorikan menjadi 2 kriteria, yaitu formal dan informal. Pendidikan formal, pangkat/Gol. ruang, diklat jabatan, pengalaman jabatan, masa kerja, dan usia merupakan sub kriteria formal untuk penempatan jabatan ASN, sedangkan inovasi, kreatifitas, serta ide bagi pengembangan fungsi lembaga, disiplin, kemampuan berkolaborasi dan kerjasama dengan tim, leadership, loyalitas, tanggung jawab, kemampuan berkomunikasi dengan baik, dan intervensi politik merupakan sub kriteria dari kriteria informal. Kemudian metode yang digunakan dalam pembobotan kriteria guna memperoleh model pengambilan keputusan penempatan jabatan struktural ASN pada Dinas Perkebunan dan Peternakan Provinsi Lampung adalah metode Soft System Methodology dengan tools Analytical Hierarcy Process (AHP).
Setelah dilakukan simulasi, maka diperoleh hasil bahwa ASN atas nama Bunawar Holil Roni, SP yang saat ini menduduki jabatan sebagai Eselon IV, memiliki peluang tertinggi untuk dapat ditempatkan sebagai Pejabat Eselon III pada Dinas Perkebunan dan Peternakan Provinsi Lampung.

\section{Saran}

Berdasarkan kesimpulan yang diperoleh, maka penulis saran yang mungkin dapat dijadikan sebagai bahan acuan, masukan, atau perbandingan, yaitu Badan Pertimbangan Jabatan dan Kepangkatan (BAPERJAKAT) harus betul-betul memperhatikan rekam jejak yang dimiliki oleh pegawai untuk dapat ditempatkan pada jabatannya baik dari segi Formal dan Informal. Kompetensi yang dimiliki pegawai baik itu kompetensi manajerial dan kompetensi bidang harus dapat menunjukkan bahwa pegawai tersebut mampu bekerja secara profesional sehingga dapat meningkatkan efektivitas dan efisiensi dalam pelaksanaan tugas pokok dan fungsi dalam instansinya. Oleh karena itu, kompetensi yang dimiliki pegawai dapat lebih ditingkatkan dengan mengikuti pendidikan dan pelatihan teknis yang berkaitan langsung dengan bidang tugas masing-masing. Diharapkan dengan adanya UU Nomor 5 Tahun 2014 Tentang ASN saat ini, ke depannya penataan birokrasi pemerintahan Indonesia semakin demokratis, akuntabel, dan transparan sehingga mampu menghasilkan pegawai-pegawai yang lebih berkompeten. Untuk mempermudah sistem penempatan jabatan struktural ASN, sebaiknya dibuat aplikasi sebagai bentuk penerapan dari AHP yang merupakan alat yang dapat digunakan untuk mengolah data penilaian sehingga diperoleh hasil lebih objektif.

\section{DAFTAR PUSTAKA}

Adhabi E, Anozie C. 2017. Literature Review for the Type of Interview in Qualitative Research. International Journal of Education 9(3): 87-92.

Bambang KY. 2001. Analytic Hierarchy Process (AHP): Sebuah Metode Pembobotan Alternatif Dalam Pembagian Dana Alokasi Umum (DAU) Studi Kasus Di Propinsi DI Yogyakarta. Jurnal Ekonomi dan Bisnis Indonesia 16 (4): 346-357.

Barusman M, Yusuf S. 2017. Soft Systems Methodology (SSM) Solusi Untuk Kompleksitas Manajemen. Lampung: Universitas Bandar Lampung.

Barusman M, Yusuf S, Redaputri AP. 2018. Decision 
Making Model of Electric Power Fulfillment in Lampung Province Using Soft System Methodology. International Journal of Energy Economics and Policy 8(1).

Checkland PB, Scholes J. 1990. Soft Systems Methodology in Action. England: John Wiley \& Sons Ltd.

García-Alonso CR, Almeda N, Salinas-Pérez JA, Gutiérrez-Colosía MR, Uriarte-Uriarte JJ, Salvador-Carulla L. 2019. A decision support system for assessing management interventions in a mental health ecosystem: The case of Bizkaia (Basque Country, Spain). PLoS ONE 14(2): e0212179.

Gerwel PC, Bodhanya S. 2015. An Application of Soft Systems Methodology in the Sugar Industry. International Journal of Qualitative Methods 14: 318-333. 10.1177/160940691501400101.

Hermawan J. 2005. Membangun Decision Support System. Yogyakarta:Andi.

Jogiyanto. 2001. Analisis \& Desain Sistem Informasi: pendekatan terstruktur teori dan praktek aplikasi bisnis. Yogyakarta:Andi.

Laudon, Kenneth C, Jane PL. 2007. Sistem Informasi Manajemen. Edisi ke-10. Terjemahan Chriswan Sungkono dan Machmudin Eka P. Jakarta: Salemba Empat.

Mahmudah, Baga LM, Amanah S. 2020. Strategi kebijakan peningkatan jumlah mahasiswa dalam memutuskan memilih program pascasarjana di departemen ESL FEM IPB. Jurnal Aplikasi Bisnis Dan Manajemen (JABM) 6(1): 154-167.
Marimin, Maghfiroh N. 2011. Aplikasi Teknik Pengambilan Keputusan Dalam Manajemen Rantai Pasok. Bogor: IPB Press.

Muhdi M, Kastawi N, Widodo S. 2017. Teknik Pengambilan Keputusan Dalam Menentukan Model Manajemen Pendidikan Menengah. Kelola: Jurnal Manajemen Pendidikan 4(2): 135-145.

Munthafa AE, Mubarokm H. 2017. Penerapan metode analytical hierarchy process dalam sistem pendukung keputusan penentuan mahasiswa berprestasi. Jurnal Siliwangi Seri Sains dan Teknologi 3(2): 192-201.

Pebakirang SI, Sutrisno A, Neyland JS. 2017. Penerapan Metode AHP (Analytical Hierarchy Process) untuk Pemilihan Supplier Suku Cadang di PLTD Bitung. JURNAL ONLINE POROS TEKNIK MESIN UNSRAT 6(1):32-44.

Robbins SP, Coulter M. 2010. Manajemen Edisi Kesepuluh. Jakarta: penerbit Erlangga.

Saaty T. 1993. Pengambilan Keputusan Bagi Para Pemimpin, Proses Hirarki Analitik untuk Pengambilan Keputusan dalam Situasi yang Kompleks. Pustaka Binama Pressindo.

Sutopo. 2006. Metodologi Penelitian Kualitatif. Surakarta: UNS.

Syamsul B, Sangkala, Muhammad Y, Hamsinah. 2017. Process Decision Making Officer Structural Determination in Department of Education Makassar City. International Journal of Scientific and Research Publications (IJSRP) 6 (7). 